\section{BRAZIULIAN JOURNAL \\ OF MEDICAL AND BIOLOGICAL RESF.ARCH}

www.bjournal.com.br
ISSN 0100-879X

Volume 43 (04) 325-408

April 2010

BIOMEDICAL SCIENCES

AND

CLINICAL INVESTIGATION

Braz J Med Biol Res, March 2010, Volume 43(4) 338-344

Identification and in vitro production of Lactobacillus antagonists from women with or without bacterial vaginosis

K.M.G.R. Branco, R.M.D. Nardi, J.L.S. Moreira, A.C. Nunes, L.M. Farias, J.R. Nicoli and M.A.R.

Carvalho

The Brazilian Journal of Medical and Biological Research is partially financed by
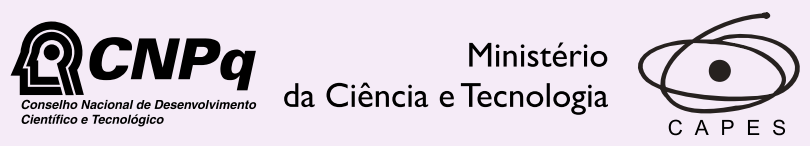

Ministério da Educação

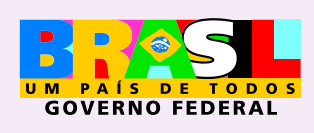

TFAPESP

Institutional Sponsors 


\title{
Identification and in vitro production of Lactobacillus antagonists from women with or without bacterial vaginosis
}

\author{
K.M.G.R. Branco ${ }^{1}$, R.M.D. Nardi ${ }^{1}$, J.L.S. Moreira ${ }^{2}$, A.C. Nunes ${ }^{2}$, L.M. Farias ${ }^{1 *}$, \\ J.R. Nicoli ${ }^{1 *}$ and M.A.R. Carvalho ${ }^{1 *}$ \\ ${ }^{1}$ Departamento de Microbiologia, ${ }^{2}$ Departamento de Biologia Geral, Instituto de Ciências Biológicas, \\ Universidade Federal de Minas Gerais, Belo Horizonte, MG, Brasil
}

\begin{abstract}
Lactobacilli isolated from the vaginal tract of women with and without bacterial vaginosis (BV) were identified and characterized for the production of antagonists. Bacterial samples were isolated from healthy women $(\mathrm{N}=16)$, from patients with clinical complaints but without BV $(\mathrm{N}=30)$, and from patients with BV $(\mathrm{N}=32)$. Identification was performed using amplified ribosomal DNA restriction analysis. Production of antagonistic compounds was evaluated by the double-layer diffusion technique using Gram-positive $(\mathrm{N}=9)$ and Gram-negative bacteria $(\mathrm{N}=6)$ as well as yeast $(\mathrm{N}=5)$ as indicator strains. Of a total of 147 isolates, 133 were identified as pertaining to the genus Lactobacillus. Lactobacillus crispatus was the species most frequently recovered, followed by $L$. johnsonii and $L$. jensenii. Statistical analysis showed that $L$. crispatus was more frequent in individuals without BV $(P<0.05)$. A higher production of antagonists was noted in $L$. crispatus isolates from healthy women $(P<0.05)$. More acidic local $\mathrm{pH}$ and higher $\mathrm{H}_{2} \mathrm{O}_{2}$ production by isolated lactobacilli from healthy women suggest these mechanisms as the possible cause of this antagonism. In conclusion, a significant correlation was detected between the presence and antagonistic properties of certain species of Lactobacillus and the clinical status of the patients.
\end{abstract}

Key words: Lactobacillus; Bacterial vaginosis; Antagonism; Hydrogen peroxide; Identification

\section{Introduction}

A healthy vaginal ecosystem is generally dominated by certain species of Lactobacillus, which exert a significant influence on the microbiology of the vagina (1). They play a protective role mainly by a combination of steric exclusion and the production of inhibitory substances (2). The lactobacilli metabolize glucose essentially to lactic acid, which contributes to the maintenance of a low vaginal $\mathrm{pH}(4.0-4.5)$ and reduces the growth of most pathogenic microorganisms. Many isolates of vaginal lactobacilli also produce $\mathrm{H}_{2} \mathrm{O}_{2}$, a compound having broad antimicrobial activity. Women colonized by $\mathrm{H}_{2} \mathrm{O}_{2}$-producing lactobacilli have been associated with decreased susceptibility to human immunodeficiency virus (HIV) infection (3) and bacterial vaginosis (BV) $(4,5)$. However, in situ $\mathrm{H}_{2} \mathrm{O}_{2}$ production by these lactobacilli has never been demonstrated.

Bacterial vaginosis affects millions of women and is associated with several serious health problems. The cause of $B V$ remains poorly understood despite numerous studies based on cell cultures (6). Bacterial vaginosis is characterized by a depletion of Lactobacillus spp and an overgrowth of diverse aerobic, anaerobic and micro-aerophilic microorganisms such as Gardnerella vaginalis, Prevotella spp, Peptostreptococcus spp, Mycoplasma hominis, Ureaplasma urealyticum, and Mobiluncus spp (7). A recent study using ribosomal DNA sequences showed that women with BV had higher bacterial diversity with many newly recognized species. Data obtained from the vaginal ecosystem of healthy women showed a lower bacterial diversity and confirmed the predominance of Lactobacillus species (8). These data suggest that, in contrast to the gastrointestinal microbial ecosystem, where potent beneficial functions of the microbiota are related to a rich biodiversity, a healthy vaginal ecosystem is characterized by a low microbial diversity consisting almost exclusively of predominant lactobacilli.

Correspondence: J.R. Nicoli, Departamento de Microbiologia, Instituto de Ciências Biológicas, UFMG, Caixa Postal 486, 30161-970 Belo Horizonte, MG, Brasil. Fax: +55-31-3409-2730. E-mail: jnicoli@icb.ufmg.br

*These authors contributed equally to this study.

Received July 3, 2009. Accepted February 11, 2010. Available online March 5, 2010. Published April 12, 2010. 
Additionally, recent data indicate that female genital-tract HIV load correlates inversely with Lactobacillus species and positively with BV (9).

There is increasing interest in the selection of particular species of Lactobacillus to serve as vaginal probiotics for the prevention of sexually transmitted infections and BV. The strains are generally selected on the basis of their dominance in the healthy vaginal ecosystem, their ability to inhibit BV pathogens in vitro, their high acid production, their production of $\mathrm{H}_{2} \mathrm{O}_{2}$, and their ability to bind exfoliated vaginal epithelial cells in vitro.

In the present study, Lactobacillus isolated in a previous study from the vaginal tract of patients with and without BV was identified by amplified ribosomal DNA restriction analysis (ARDRA) and characterized for the in vitro production of antagonistic substances to evaluate if some correlation exists between the presence and antagonistic properties of certain species of Lactobacillus and the clinical status of the patients.

\section{Material and Methods}

\section{Ethical aspects}

This project was approved by the Ethics Committee of the Federal University of Minas Gerais (ETIC \#062/03) and written informed consent was obtained from all subjects before inclusion in the study.

\section{Patients}

The bacterial samples were isolated from healthy women $(\mathrm{N}=16)$, patients with clinical complaints (human papilloma virus, herpes, candidiasis), but without $\mathrm{BV}(\mathrm{N}=30)$, and patients with $\mathrm{BV}(\mathrm{N}=32)$. Patients were screened the Gynecology Service, University Hospital, Federal University of Minas Gerais, Belo Horizonte, MG, Brazil.

\section{Lactobacillus isolates}

A total of 147 bacteria isolated from the subjects were selected as presumptive Lactobacillus based on the following characteristics: Gram-positive micro-aerophilic and catalase-negative rods isolated on de Man, Rogosa and Sharp (MRS) agar (Merck, Germany) at $37^{\circ} \mathrm{C}$. The bacterial samples were maintained at $-80^{\circ} \mathrm{C}$ in MRS broth medium (Difco, USA) supplemented with 10\% glycerol.

\section{DNA extraction}

Chromosomal DNA was isolated from overnight cultures of all isolates in $10 \mathrm{~mL}$ MRS broth. After washing the cells with deionised water, the pellet was obtained by centrifugation at $14,000 \mathrm{~g}$ for $5 \mathrm{~min}$ at $4^{\circ} \mathrm{C}$, suspended in $1 \mathrm{~mL} 5 \mathrm{M} \mathrm{LiCl}$, and incubated for $1 \mathrm{~h}$ with constant shaking. After a second washing with $1 \mathrm{~mL}$ deionized water, the pellet was suspended in $1 \mathrm{~mL}$ protoplasting buffer (50 $\mathrm{mM}$ Tris- $\mathrm{HCl}, \mathrm{pH}$ 8.0, $10 \mathrm{mM}$ EDTA, $10 \mathrm{mg} / \mathrm{mL}$ lysozyme, $100 \mu \mathrm{g} / \mathrm{mL}$ RNAse). After incubation for $1 \mathrm{~h}$ at $37^{\circ} \mathrm{C}$ and centrifugation at $14,000 \mathrm{~g}$ for $5 \mathrm{~min}$ at $4^{\circ} \mathrm{C}$, the pellet was suspended in $500 \mu \mathrm{L}$ protoplasting buffer without lysozyme and $100 \mu \mathrm{L} 10 \%$ sodium dodecyl sulfate was added to allow cells to lyse. After lysis, the mixture was extracted once with phenol, phenol-chloroform-isoamyl alcohol (25:24:1) and chloroform-isoamyl alcohol (24:1). After isopropanol precipitation, the DNA was dissolved in $100 \mu \mathrm{L}$ TE buffer (10 mM Tris- $\mathrm{HCl}, 1 \mathrm{mM}$ EDTA, $\mathrm{pH}$ 8.0).

\section{PCR amplification of the 16S-23S rDNA intergenic spacer}

The 16S-23S intergenic spacer region was amplified by the method of Moreira et al. (10) using the primer 161A (GAATCGCTAGTAATCG) that anneals to a conserved region of the 16S rRNA genes, and primer 23-1B (GGGTT CCCCCATTCGGA) that anneals to a conserved region of the 23S rRNA genes using a PTC-100 ${ }^{\circledR}$ Thermal cycler (MJ Research Inc., USA). The reaction mixture $(50 \mu \mathrm{L})$ contained $10 \mathrm{pM}$ of each primer, $0.2 \mathrm{mM}$ of each deoxyribonucleotide triphosphate, reaction buffer containing $1.5 \mathrm{mM} \mathrm{MgCl}_{2}, 5 \mathrm{U}$ Taq DNA polymerase (Phoneutria Biotecnologia \& Serviços, Brazil), and $5 \mu \mathrm{L}$ of template DNA solution. The amplification program was $95^{\circ} \mathrm{C}$ for $2 \mathrm{~min}, 35$ cycles of $95^{\circ} \mathrm{C}$ for $30 \mathrm{~s}$, $55^{\circ} \mathrm{C}$ for $1 \mathrm{~min}, 72^{\circ} \mathrm{C}$ for $1 \mathrm{~min}$, and finally $72^{\circ} \mathrm{C}$ for $10 \mathrm{~min}$. PCR products were electrophoresed on $1.4 \%$ agarose gel and visualized by UV transillumination after staining with an ethidium bromide solution $(5 \mu \mathrm{g} / \mathrm{mL})$.

\section{Amplified ribosomal DNA restriction analysis}

ARDRA of 16S-23S rRNA intergenic regions was performed by the method of Moreira et al. (10). Briefly, the 16S-23S rRNA intergenic spacer regions of lactic acid bacteria were amplified by PCR and digested with a set of 12 enzymes chosen after compilation of nucleotide sequences already deposited at GenBank and in silico restriction digestion using the Webcutter 2.0 tool (Max Heiman 1997; http://rna.lundberg.gu.se/cutter2/). Sphl, Ncol and Nhel enzymes hydrolyzed inside the 16S gene; Sspl, Sful, Dral, Vspl, Hincll, and EcoRI enzymes hydrolyzed inside the intergenic region, and Avrll and HindIII enzymes hydrolyzed inside the 235 gene. EcoRV enzyme hydrolyzed inside the spacer region for the $L$. casei group and in the $23 S$ gene for $L$. acidophilus group. For several lactobacillus species no spacer nucleotide sequences have been reported and only fragments of the $16 \mathrm{~S}$ and/or 23S genes were found. All restriction enzymes were purchased from Promega Corporation (USA).

\section{In vitro antagonism assay}

The isolated bacteria were cultured in MRS broth for $24 \mathrm{~h}$ at $37^{\circ} \mathrm{C}$ in an anaerobic chamber (Forma Scientific Company, USA) containing an atmosphere of $85 \% \mathrm{~N}_{2}, 10 \%$ $\mathrm{H}_{2}$ and $5 \% \mathrm{CO}_{2}$. After growth, an aliquot $(5 \mu \mathrm{L})$ of the culture was spotted onto MRS agar (Difco). After incubation at $37^{\circ} \mathrm{C}$ for $48 \mathrm{~h}$ under anaerobic conditions, the cells were killed 
by exposure to chloroform for $20 \mathrm{~min}$. Residual chloroform was allowed to evaporate and Petri dishes were overlaid with $3.5 \mathrm{~mL}$ brain heart infusion, MRS or Sabouraud soft agar $(0.7 \%)$ (Difco), which had been inoculated with 0.2 $\mathrm{mL}$ of a $24-\mathrm{h}$ culture of $L$. casei ATCC 334 , L. plantarum ATCC 8014, L. acidophilus ATCC 4356, L. delbrueckii subsp lactis ATCC 7830, L. brevis ATCC 367, L. fermentum ATCC 9338, Staphylococcus aureus ATCC 33591, Enterococcus faecalis ATCC 4083, Prevotella intermedia ATCC 25611, Bacteroides fragilis ATCC 25285, Bifidobacterium bifidum ATCC 29521, Proteus vulgaris ATCC 6380, Pseudomonas aeruginosa ATCC 27853, Gardnerella vaginalis ATCC 14018, Mobiluncus mulieris ATCC 35239, Candida albicans ATCC 18804, C. glabrata ATCC 2001, C. krusei ATCC 20298, C. parapsilosis ATCC 22019, or C. tropicalis ATCC 750 . After $24 \mathrm{~h}$ of incubation at $37^{\circ} \mathrm{C}$ under aerobic or anaerobic conditions depending on the indicator strain, the antagonistic activity was determined as the presence of a growth inhibition zone using the method of Tagg as modified by Gomes et al. (11).

\section{Determination of hydrogen peroxide production}

To test for the production of $\mathrm{H}_{2} \mathrm{O}_{2}$ by lactobacillus isolates, a qualitative assay on tetramethylbenzidine (TMB; Sigma, USA) agar plates was done as described by Rabe and Hillier (12). Lactobacilli were inoculated onto TMB agar plates and incubated in the anaerobic chamber at $37^{\circ} \mathrm{C}$. After $40 \mathrm{~h}$, the plates were exposed to ambient air. If the lactobacilli produce
$\mathrm{H}_{2} \mathrm{O}_{2}$, a reaction occurred with horseradish peroxidase (Sigma) present in the medium, which oxidizes TMB, causing the colonies to turn blue. L. acidophilus ATCC 4356 was used as control.

\section{Statistical analysis}

Data were analyzed using the Minitab Release 14.20 software (Minitab Inc., Copyright ${ }^{\odot}$ 2005). The MannWhitney rank sum test, the Fisher exact test and KruskalWallis one-way analysis of variance followed by pair-wise multiple comparison using the Student-Newman-Keuls method were used. $P<0.05$ was considered to be statistically significant.

\section{Results}

A total of 147 presumptive Lactobacillus samples were isolated in a previous study (Soares-Brandão KLK, unpublished results) from healthy women, patients with clinical complaints but without BV, and patients with BV.

Among these isolates, 133 were confirmed as pertaining to the genus Lactobacillus by ARDRA and then characterized for in vitro production of antagonistic substances. Table 1 shows that the frequency of subjects presenting at least one Lactobacillus isolate was apparently higher in healthy women (87.5\%) than in the two other groups $(66.7$ and $65.6 \%$ for patients with clinical complaints but without $\mathrm{BV}$ and patients with $\mathrm{BV}$, respectively). However, statistical

Table 1. Total number and percent of women harboring the Lactobacillus species in dominant levels isolated from healthy women, from patients with complaints but without bacterial vaginosis (BV), and from patients with BV.

\begin{tabular}{lccc}
\hline & Healthy $(\mathrm{N}=16)$ & With complaints $(\mathrm{N}=30)$ & With BV $(\mathrm{N}=32)$ \\
\hline Lactobacillus $^{*}$ & $14(87.5)^{\mathrm{a}}$ & $20(66.7)^{\mathrm{a}}$ & $21(65.6)^{\mathrm{a}}$ \\
L. crispatus $^{\mathrm{a}}$ & $15(57.1)^{\mathrm{a}}$ & $24(60.0)^{\mathrm{a}}$ & $5(13.6)^{\mathrm{b}}$ \\
L. johnsonii & $6(21.4)^{\mathrm{a}, \mathrm{b}}$ & $9(15.0)^{\mathrm{a}}$ & $15(45.5)^{\mathrm{b}}$ \\
L. jensenii & $2(21.4)^{\mathrm{a}}$ & $8(20.0)^{\mathrm{a}}$ & $13(36.4)^{\mathrm{a}}$ \\
L. reuteri & $1(7.1)$ & $1(5.0)$ & $5(18.2)$ \\
L. rhamnosus & $1(7.1)$ & $1(5.0)$ & $4(13.6)$ \\
L. agilis & $1(7.1)$ & $3(15.0)$ & $1(4.6)$ \\
L. gasseri & $1(7.1)$ & $1(5.0)$ & $2(9.1)$ \\
L. acidophilus & $1(7.1)$ & $2(5.0)$ & $0(0)$ \\
L. delbrueckii & $2(14.3)$ & $0(0)$ & $0(0)$ \\
L. vaginalis & $0(0)$ & $0(0)$ & $2(9.1)$ \\
L. fermentum & $0(0)$ & $0(0)$ & $2(3.6)$ \\
L. brevis & $1(7.1)$ & $0(0)$ & $0(0)$ \\
Lactobacillus spp & $0(0)$ & $0(0)$ & $4(9.1)$ \\
Total & 31 & 49 & 53 \\
\hline
\end{tabular}

*Subjects with at least one Lactobacillus isolate. Isolates were identified by amplified ribosomal DNA restriction analysis using the $16 \mathrm{~S}-23 \mathrm{~S}$ intergenic regions. Data are reported as total number with percent in parentheses. ${ }^{a, b}$ Different letters on the same line indicate significant differences by the Fisher exact test $(P<0.05)$. 
Table 2. Mean antagonism frequency $(\% \pm S D)$ against all indicator strains produced by Lactobacillus crispatus, $L$. johnsonii and $L$. jensenii isolated from healthy women, from patients with complaints but without bacterial vaginosis (BV), and from patients with BV.

\begin{tabular}{llll}
\hline & \multicolumn{1}{c}{ L. crispatus } & \multicolumn{1}{c}{ L. johnsonii } & \multicolumn{1}{c}{ L. jensenii } \\
\hline Healthy & $63.7 \pm 30.9^{\mathrm{a} 1}(15)$ & $45.8 \pm 38.5^{\mathrm{a} 2}(6)$ & $47.5 \pm 37.9^{\mathrm{a} 2}(2)$ \\
With complaints & $35.5 \pm 23.8^{\mathrm{b} 1}(24)$ & $42.7 \pm 31.6^{\mathrm{a} 1}(9)$ & $15.0 \pm 19.4^{\mathrm{b} 2}(8)$ \\
With BV & $18.0 \pm 22.4^{\mathrm{c} 1}(5)$ & $25.3 \pm 22.3^{\mathrm{b} 1}(15)$ & $21.8 \pm 19.9^{\mathrm{b} 1}(13)$ \\
\hline
\end{tabular}

The total number of Lactobacillus isolates of each species tested against 20 indicator strains is reported in parentheses. a,b,cDifferent letters in the same column indicate significant differences by Kruskal-Wallis one-way analysis of variance followed by pairwise multiple comparison using the Student-Newman-Keuls test $(P<0.05)$. 1,2Different numbers on the same line indicate significant differences by KruskalWallis one-way analysis of variance followed by pairwise multiple comparison using the Student-Newman-Keuls test $(P<0.05)$.

Table 3. Susceptibility (\%) of each indicator strain to antagonism produced by all Lactobacillus species isolated from healthy women, from patients with complaints but without bacterial vaginosis (BV), or from patients with BV.

\begin{tabular}{lccc}
\hline & $\begin{array}{c}\text { Healthy } \\
(\mathrm{N}=16)\end{array}$ & $\begin{array}{c}\text { With complaints } \\
(\mathrm{N}=30)\end{array}$ & $\begin{array}{c}\text { With BV } \\
(\mathrm{N}=32)\end{array}$ \\
\hline L. acidophilus & $90.2^{*}(92.9)^{\star *}$ & $51.0(85.0)$ & $22.6(36.4)$ \\
L. brevis & $22.6(28.6)$ & $6.1(5.0)$ & $15.1(22.7)$ \\
L. plantarum & $61.3(64.3)$ & $20.4(35.0)$ & $15.1(18.2)$ \\
L. delbrueckii & $71.0(64.3)$ & $34.7(70)$ & $18.9(27.3)$ \\
L. fermentum & $83.9(76.6)$ & $34.7(75.0)$ & $28.2(36.4)$ \\
L. casei & $35.5(35.7)$ & $24.5(45.0)$ & $20.8(31.8)$ \\
S. aureus & $51.6(85.7)$ & $26.5(75.0)$ & $22.6(31.8)$ \\
B. bifidum & $38.7(64.3)$ & $32.7(55.0)$ & $15.1(22.7)$ \\
E. faecalis & $25.8(28.6)$ & $8.2(15.0)$ & $11.3(4.6)$ \\
G. vaginalis & $77.4(64.3)$ & $59.2(95.0)$ & $20.8(40.9)$ \\
M. mulieris & $74.2(78.6)$ & $32.7(90.0)$ & $11.3(31.8)$ \\
B. fragilis & $93.6(85.7)$ & $69.4(90.0)$ & $75.4(95.5)$ \\
P. intermedia & $77.4(92.9)$ & $65.3(100)$ & $75.4(81.8)$ \\
P. aeruginosa & $38.7(28.6)$ & $6.1(10.0)$ & $17.0(4.6)$ \\
P. vulgaris & $58.1(64.3)$ & $28.6(35.0)$ & $22.6(27.3)$ \\
C. krusei & $0(0)$ & $0(0)$ & $1.9(4.6)$ \\
C. parapsilosis & $25.8(24.4)$ & $8.2(20.0)$ & $3.8(9.1)$ \\
C. albicans & $48.4(57.1)$ & $26.5(50.0)$ & $13.2(27.3)$ \\
C. glabrata & $54.8(71.4)$ & $22.5(30.0)$ & $7.6(18.2)$ \\
C. tropicalis & $77.4(64.3)$ & $55.1(80.0)$ & $22.6(36.4)$ \\
Mean & $55.3^{\mathrm{a}}(58.6)^{\mathrm{a}}$ & $\left.30.6^{\mathrm{b}}(53.0)^{\mathrm{a}}\right)$ & $22.1^{\mathrm{b}}(30.5)^{\mathrm{b}}$ \\
\hline
\end{tabular}

*Number of Lactobacillus positive for antagonism/total number of Lactobacillus tested. Positive/negative tests were determined as presence/absence of inhibitory zone. ${ }^{* *}$ Number of patients with Lactobacillus positive for antagonism/total number of patients. ${ }^{a, b}$ Different letters indicate significant differences by the Mann-Whitney rank sum test $(P<0.05)$. analysis of these data showed a tendency but not a significant difference $(P=0.10)$. Considering all groups, L. crispatus was the species most frequently recovered (33.1\% of the 133 isolates), followed by $L$. johnsonii (22.6\%) and L. jensenii (17.3\%). In healthy women, a mean value of 1.94 Lactobacillus species/individual was observed. Statistical analysis showed that $L$. crispatus was more frequent in individuals without BV ( $\mathrm{P}<0.05)$, whereas L. johnsonii and $L$. jensenii tended to be most frequently found in patients with BV.

Table 2 shows the overall antagonistic capacity as the mean growth inhibition frequencies against all the indicator strains of the three more frequently isolated Lactobacillus species (L. crispatus, L. johnsonii, and L. jensenii). L. crispatus isolates from healthy women showed the highest antagonistic or inhibitory ability $(P$ $<0.05$ ), either when compared with the two other Lactobacillus species from the same group of women or when compared with $L$. crispatus isolates from the other two patient groups. In patients with BV, all the Lactobacillus isolates, independently of the species, showed similar low antagonistic or inhibitory capacity.

Table 3 shows that, independently of indicator strains, a higher frequency $(P<$ 0.05 ) of antagonism was noted for Lactobacillus species isolated from healthy women $(55.3 \%)$ when compared to those from both patients with complaints but without BV $(30.6 \%)$ and with BV $(22.1 \%)$. Among indicator strains, L. acidophilus, $L$. fermentum and $B$. fragilis were the most sensitive, followed by important pathogens such as $G$. vaginalis and $M$. mulieris.

Table 4 shows a significantly higher frequency $(\mathrm{P}<0.05)$ of cells producing $\mathrm{H}_{2} \mathrm{O}_{2}$ by all Lactobacillus species isolated from healthy women (all of them, except one L. brevis isolate, 96.8\%) when compared to those from both patients with complaints but without BV $(65.3 \%)$ or with $\mathrm{BV}(35.8 \%)$. This difference is due to a progressive decrease of antagonistic activity for practically all Lactobacillus species, but with a higher reduction for $L$. jensenii and $L$. johnsonii isolates. For example, isolates of the three predominant species produced more frequently $\mathrm{H}_{2} \mathrm{O}_{2}$ 
Table 4. Number and percent of Lactobacillus species producing hydrogen peroxide isolated from healthy women, from patients with complaints but without bacterial vaginosis (BV) and from patients with BV.

\begin{tabular}{lcccc}
\hline & Healthy $(\mathrm{N}=16)$ & With complaints $(\mathrm{N}=30)$ & With BV $(\mathrm{N}=32)$ & Total $(\mathrm{N}=78)$ \\
\hline L. crispatus & $15 / 15(100)^{\mathrm{a}}$ & $20 / 24(83.3)^{\mathrm{ab}}$ & $2 / 5(40.0)^{\mathrm{a}}$ & $37 / 44(84.1)$ \\
L. johnsonii & $6 / 6(100)^{\mathrm{a}}$ & $1 / 9(11.1)^{\mathrm{b}}$ & $4 / 15(26.7)^{\mathrm{b}}$ & $11 / 30(36.7)$ \\
L. jensenii & $2 / 2(100)^{\mathrm{a}}$ & $5 / 8(62.5)^{\mathrm{a}}$ & $2 / 13(15.4)^{\mathrm{b}}$ & $9 / 23(39.1)$ \\
L. reuteri & $1 / 1(100)$ & $1 / 1(100)$ & $1 / 5(20.0)$ & $3 / 7(42.9)$ \\
L. rhamnosus & $1 / 1(100)$ & $1 / 1(100)$ & $3 / 4(75.0)$ & $5 / 6(83.3)$ \\
L. agilis & $1 / 1(100)$ & $2 / 3(66.7)$ & $0 / 1(0)$ & $3 / 5(60.0)$ \\
L. gasseri & $1 / 1(100)$ & $0 / 1(0)$ & $1 / 2(50.0)$ & $2 / 4(50.0)$ \\
L. acidophilus & $1 / 1(100)$ & $2 / 2(100)$ & - & $3 / 3(100)$ \\
L. delbrueckii & $2 / 2(100)$ & - & - & $2 / 2(100)$ \\
L. vaginalis & - & - & $2 / 2(100)$ & $2 / 2(100)$ \\
L. fermentum & - & - & $1 / 2(50.0)$ & $1 / 2(50.0)$ \\
L. brevis & $0 / 1(0)$ & - & - & $0 / 1(0)$ \\
Lactobacillus spp & - & - & $3 / 4(75.0)$ & $3 / 4(75.0)$ \\
Total $(\%)$ & $30 / 31(96.8)^{\mathrm{a}}$ & $32 / 49(65.3)^{\mathrm{b}}$ & $19 / 53(35.8)^{\mathrm{c}}$ & $81 / 133(60.9)$ \\
\hline
\end{tabular}

Hydrogen peroxide was measured as described originally by Rabe and Hillier (12). ${ }^{a, b, c}$ Different letters on the same line indicate significant differences by the Fisher exact test $(P<0.05)$.

$(P<0.05)$ when recovered from healthy women $(100 \%$ of L. crispatus, L. johnsonii and L. jensenii) than when isolated from patients with complaints but without $B V(83.3,11.1$ and $62.5 \%$ of $L$. crispatus, $L$. johnsonii, and $L$. jensenii, respectively) or with BV $(40.0,26.7$, and $15.4 \%$ of $L$. crispatus, $L$. johnsonii, and L. jensenii, respectively).

Determination of vaginal $\mathrm{pH}$ suggested a relationship between local acidic $\mathrm{pH}$ and $\mathrm{BV}$ symptoms. Most of the healthy women $(93.3 \%)$ and patients with complaints but without BV $(89.3 \%)$ had a vaginal $\mathrm{pH}$ value lower than 4.5 , whereas this value was observed only in $50 \%$ of patients with BV $(P<0.05)$. Additionally, L. crispatus tended to be more frequently $(85.7 \%)$ isolated from women with lower vaginal $\mathrm{pH}$ values when compared to $L$. johnsonii $(64.3 \%$, $\mathrm{P}=0.14)$ and $L$. jensenii $(61.5 \%, \mathrm{P}=0.11)$.

\section{Discussion}

A recent USA study showed that $L$. acidophilus and $L$. fermentum were the primary species colonizing the vagina of adolescent women, but the results were obtained using phenotypic identification methods such as biochemical assays (13). However, the group of organisms previously known as L. acidophilus was shown to be highly heterogeneous, and was divided subsequently into DNA homology groups Aand $B$ to form the six separate species: $L$. acidophilus (A1), $L$. crispatus (A2), L. amylovorus (A3), L. gallinarum (A4), L. gasseri (B1), and L. johnsonii (B2) (14). L. jensenii and $L$. iners are other common lactobacilli found in the human vagina $(15,16)$. The closely related species within the $L$. acidophilus complex are quite difficult and sometimes impossible to differentiate by phenotypic methods. Consequently, accurate genomic methods, such as ARDRA (10), are needed in order to define the Lactobacillus microbiota in the vagina. Additionally, some Lactobacillus species, such as L. iners, do not grow on Rogosa or MRS media traditionally used for lactobacillus recovery (16). This species seems to be dominant both among white (17) and black women (18). However, due to its culture characteristic (growth only on blood agar), its antagonistic ability is not known.

Our results are in general agreement with other studies $(17,19,20)$ showing that only one or a few Lactobacillus species colonize the healthy human vagina (1.94 species/individual) and that species within the $L$. acidophilus complex predominate (L. crispatus). Antonio et al. (21) applying whole-chromosome DNA probes and Vásquez et al. (17) using randomly amplified polymorphic DNA analysis, TTGE multiplex PCR and $16 \mathrm{~S}$ ribosomal DNA sequencing showed a dominance of $L$. iners, L. crispatus, L. gasseri, and $L$. jensenii. In a comparative study between Gram stain of vaginal smears (Nugent's criteria) and tDNA-PCR identification of vaginal cultivable species, Verhelst et al. (20) found that $L$. crispatus was the only Lactobacillus species linked to a single grade (as determined by Gram stain-based grading of vaginal smears), namely grade la, while the other lactobacilli were more evenly distributed over all specimens. In this same study, the number of Lactobacillus species per individual presenting grade I microbiota ranged from 1.5 to 2.0. Recent results obtained by Antonio et al. (19) also suggest that rectal colonization by $L$. crispatus may contribute to the maintenance of a healthy vaginal microbiota.

Lactic acid bacteria play a significant physiological role in the maintenance of the ecological balance mainly because their lactic acid production is responsible for a low $\mathrm{pH}$ level 
in the tracts. In addition, they also produce many other growth inhibitory substances such as hydrogen peroxide, bacteriocins or lactocins, and some organic acids. Other mechanisms proposed for their microbial antagonism are competition for nutrients, inhibition of pathogen adhesion to surfaces, and stimulation of the immune system. The results obtained here in the in vitro antagonism assays (Tables 2 and 3) showed that the Lactobacillus isolated from the healthy women presented a higher ability to produce diffusible compounds against potential pathogenic bacteria ( $G$. vaginalis, $M$. mulieris), as well as against other Lactobacillus species than those isolated from patients with complaints and without BV or with BV. Interestingly, L. acidophilus and $L$. fermentum were among the most sensitive indicator strains, and this fact might be an explanation for their low isolation frequencies (Table 1). Among the most frequently recovered Lactobacillus species, L. crispatus showed the highest antagonistic capacity, but only when isolated from healthy women (Table 2). However, the in vitro antagonism assay used in the present study is not specific and only demonstrates the production of one or more diffusible inhibitory substance(s), which could be $\mathrm{H}_{2} \mathrm{O}_{2}$, organic acids and/or bacteriocins.

$L$. crispatus and $L$. jensenii are considered to be the main $\mathrm{H}_{2} \mathrm{O}_{2}$ producers, and the presence of these bacteria has been positively associated with being white, older than 20 years, using barrier contraception, and having a low frequency of BV and gonorrhea (21). In a screening study, Ocanã et al. (22) also observed that among Lactobacillus strains isolated from healthy women, an L. crispatus strain produced the highest level of $\mathrm{H}_{2} \mathrm{O}_{2}$. A recent study indicated that douching frequently and having multiple sex partners increase the risk of the absence of protective $\mathrm{H}_{2} \mathrm{O}_{2}$-producing lactobacilli among women with $\mathrm{BV}$ (23). On the other hand, the same report showed that the use of metronidazole might favor the presence of $\mathrm{H}_{2} \mathrm{O}_{2}$-producing lactobacilli in the vaginal microenvironment. In the present study, $L$. crispatus was also observed to be the most frequent $\mathrm{H}_{2} \mathrm{O}_{2}$ producer among the Lactobacillus species isolated from healthy women. However, the same species did not exhibit this ability when recovered from patients with BV. During an 8-month study, Vallor et al. (2) showed that, in contrast to $L$. crispatus and $L$. jensenii $\mathrm{H}_{2} \mathrm{O}_{2}$-producing isolates, strains that did not produce the antimicrobial substance were rapidly lost, a fact that supports the role of this production in sustained colonization. However, as

\section{References}

1. Aroutcheva A, Gariti D, Simon M, Shott S, Faro J, Simoes JA, et al. Defense factors of vaginal lactobacilli. Am J Obstet Gynecol 2001; 185: 375-379.

2. Vallor AC, Antonio MA, Hawes SE, Hillier SL. Factors associated with acquisition of, or persistent colonization by, vaginal lactobacilli: role of hydrogen peroxide production. $J$ demonstrated by diffusion assays, there is not always a direct correlation between the ability for $\mathrm{H}_{2} \mathrm{O}_{2}$ production and the antagonistic activity of lactobacilli (24). In fact, the potential of $\mathrm{H}_{2} \mathrm{O}_{2}$ production by Lactobacillus described here and in the literature has been demonstrated by in vitro assays and one must be cautious when extrapolating it to the in vivo environment.

Many investigators believe that lactic acid production is a primary mechanism for maintaining the equilibrium of a healthy vaginal ecosystem, creating an inhospitable environment for the growth of pathogenic microorganisms. A low $\mathrm{pH}$ is not favorable for the growth of $G$. vaginalis (optimal $\mathrm{pH} 6.0$ to 6.5) or of various obligate anaerobes, such as $P$. bivia and Peptostreptococcus spp (optimal pH 5.5 to 6.0) (25). The presence of lactobacilli and the number of their bacterial cells in the vaginal environment are responsible for $\mathrm{pH}$ changes. The results of the present study suggest that the Lactobacillus species is also an important factor since women with vaginal $\mathrm{pH}$ values lower than 4.5 are preferentially associated with $L$. crispatus. Aroutcheva et al. (1) described very different in vitro growth and acid production rates depending on the species of Lactobacillus isolated from the human vagina and these characteristics could explain the specific presence of $L$. crispatus in healthy women. Additionally, the activity of $\mathrm{H}_{2} \mathrm{O}_{2}$ is influenced by the hydrogen ion concentration in the environment. Hydrogen peroxide is stable under acidic conditions and is degraded as the hydrogen ion concentration decreases (26).

Among cultivable lactobacilli, $L$. crispatus seems to be an important species apparently associated with a healthy vaginal ecosystem. However, this bacterium is important for a healthy vaginal ecosystem not only in quantitative terms, but also for its metabolic properties (antagonism). Presumably, hydrogen peroxide and acid production is a mechanism responsible for the predominance and protective characteristics of this Lactobacillus species. However, other antagonistic abilities cannot be excluded, such as production of bacteriocin or competition for adhesion sites and nutrients.

\section{Acknowledgments}

The authors are grateful to Maria Gorete Barbosa Ribas, Luzia Rosa Resende and José Sérgio Barros de Souza, for valuable technical help.
Infect Dis 2001; 184: 1431-1436.

3. Bowers R. 'Good bacteria' may aid in slowing HIV spread. AIDS Alert 2008; 23: 67-68.

4. Strus M, Brzychczy-Wloch M, Gosiewski T, Kochan P, Heczko PB. The in vitro effect of hydrogen peroxide on vaginal microbial communities. FEMS Immunol Med Microbiol 2006; 
48: 56-63.

5. Cherpes TL, Hillier SL, Meyn LA, Busch JL, Krohn MA. A delicate balance: risk factors for acquisition of bacterial vaginosis include sexual activity, absence of hydrogen peroxide-producing lactobacilli, black race, and positive Herpes simplex virus type 2 serology. Sex Transm Dis 2008; 35: 78-83.

6. Forsum U, Holst E, Larsson PG, Vasquez A, Jakobsson T, Mattsby-Baltzer I. Bacterial vaginosis - a microbiological and immunological enigma. APMIS 2005; 113: 81-90.

7. Srinivasan S, Fredricks DN. The human vaginal bacterial biota and bacterial vaginosis. Interdiscip Perspect Infect Dis 2008; 2008: 750479.

8. Dumonceaux TJ, Schellenberg J, Goleski V, Hill JE, Jaoko W, Kimani J, et al. Multiplex detection of bacteria associated with normal microbiota and with bacterial vaginosis in vaginal swabs by use of oligonucleotide-coupled fluorescent microspheres. J Clin Microbiol 2009; 47: 4067-4077.

9. Sha BE, Zariffard MR, Wang QJ, Chen HY, Bremer J, Cohen $\mathrm{MH}$, et al. Female genital-tract HIV load correlates inversely with Lactobacillus species but positively with bacterial vaginosis and Mycoplasma hominis. J Infect Dis 2005; 191: 25-32.

10. Moreira JL, Mota RM, Horta MF, Teixeira SM, Neumann E, Nicoli JR, et al. Identification to the species level of Lactobacillus isolated in probiotic prospecting studies of human, animal or food origin by $16 \mathrm{~S}-23 \mathrm{~S}$ rRNA restriction profiling. BMC Microbiol 2005; 5: 15.

11. Gomes DA, Souza AM, Lopes RV, Nunes AC, Nicoli JR. Comparison of antagonistic ability against enteropathogens by $\mathrm{G}+$ and G- anaerobic dominant components of human fecal microbiota. Folia Microbiol 2006; 51: 141-145.

12. Rabe LK, Hillier SL. Optimization of media for detection of hydrogen peroxide production by Lactobacillus species. $J$ Clin Microbiol 2003; 41: 3260-3264.

13. Alvarez-Olmos MI, Barousse MM, Rajan L, Van Der Pol BJ, Fortenberry D, Orr D, et al. Vaginal lactobacilli in adolescents: presence and relationship to local and systemic immunity, and to bacterial vaginosis. Sex Transm Dis 2004; 31: 393-400.

14. Fujisawa T, Benno Y, Yaeshima T, Mitsuoka T. Taxonomic study of the Lactobacillus acidophilus group, with recognition of Lactobacillus gallinarum sp. nov. and Lactobacillus johnsonii sp. nov. and synonymy of Lactobacillus acidophilus group A3 (Johnson et al. 1980) with the type strain of Lactobacillus amylovorus (Nakamura 1981). Int J Syst Bacteriol 1992; 42: 487-491.
15. Martin R, Soberon N, Vaneechoutte M, Florez AB, Vazquez $F$, Suarez JE. Characterization of indigenous vaginal lactobacilli from healthy women as probiotic candidates. Int Microbiol 2008; 11: 261-266.

16. Falsen E, Pascual C, Sjoden B, Ohlen M, Collins MD. Phenotypic and phylogenetic characterization of a novel Lactobacillus species from human sources: description of Lactobacillus iners sp. nov. Int J Syst Bacteriol 1999; 49 (Part 1): 217-221.

17. Vásquez A, Jakobsson T, Ahrne S, Forsum U, Molin G. Vaginal Lactobacillus flora of healthy Swedish women. J Clin Microbiol 2002; 40: 2746-2749.

18. Anukam KC, Osazuwa EO, Ahonkhai I, Reid G. LactobacilIus vaginal microbiota of women attending a reproductive health care service in Benin city, Nigeria. Sex Transm Dis 2006; 33: 59-62.

19. Antonio MA, Rabe LK, Hillier SL. Colonization of the rectum by Lactobacillus species and decreased risk of bacterial vaginosis. J Infect Dis 2005; 192: 394-398.

20. Verhelst R, Verstraelen H, Claeys G, Verschraegen G, Van Simaey L, De Ganck C, et al. Comparison between Gram stain and culture for the characterization of vaginal microflora: definition of a distinct grade that resembles grade I microflora and revised categorization of grade I microflora. BMC Microbiol 2005; 5: 61.

21. Antonio MA, Hawes SE, Hillier SL. The identification of vaginal Lactobacillus species and the demographic and microbiologic characteristics of women colonized by these species. J Infect Dis 1999; 180: 1950-1956.

22. Ocanã VS, Pesce De Ruiz Holgado AA, Nader-Macias ME. Selection of vaginal $\mathrm{H}_{2} \mathrm{O}_{2}$-generating Lactobacillus species for probiotic use. Curr Microbiol 1999; 38: 279-284.

23. Beigi RH, Wiesenfeld HC, Hillier SL, Straw T, Krohn MA. Factors associated with absence of $\mathrm{H}_{2} \mathrm{O}_{2}$-producing Lactobacillus among women with bacterial vaginosis. J Infect Dis 2005; 191: 924-929.

24. Mastromarino P, Brigidi P, Macchia S, Maggi L, Pirovano F, Trinchieri V, et al. Characterization and selection of vaginal Lactobacillus strains for the preparation of vaginal tablets. $J$ Appl Microbiol 2002; 93: 884-893.

25. Biswas MK. Bacterial vaginosis. Clin Obstet Gynecol 1993; 36: 166-176.

26. Fontaine EA, Taylor-Robinson D. Comparison of quantitative and qualitative methods of detecting hydrogen peroxide produced by human vaginal strains of lactobacilli. J Appl Bacteriol 1990; 69: 326-331. 